\title{
ANALISIS HASIL KONVERSI ECO ENZYME MENGGUNAKAN NENAS (Ananas comosus ) DAN PEPAYA (Carica papaya L.)
}

\author{
Neny Rochyani ${ }^{1}$, Rih Laksmi Utpalasari ${ }^{2)}$, Inka Dahliana ${ }^{3}$ ) \\ ${ }^{1}$ Ilmu Perikanan Fakultas Perikanan Universitas PGRI Palembang \\ ${ }^{2}$ Ilmu Perikanan Fakultas Perikanan Universitas PGRI Palembang \\ ${ }^{3)}$ MIPA Biologi Fakultas MIPA Universitas PGRI Palembang \\ Email:nenyrochyani@yahoo.com ${ }^{1}$,Saripala@yahoo.com ${ }^{2}$, \\ inkadahlianahrohim@gmail.com ${ }^{3}$
}

\begin{abstract}
Abstrak
Penelitian ini memfokuskan pada analisis Hasil Konversi Eco Enzyme menggunakan Nenas (Ananas comosus) dan Pepaya (Carica papaya L.) yang bertujuan untuk mengetahui analisis kimia hasil fermentasi eco enzyme dengan menggunakan bahan baku nenas dan pepaya. Buah pepaya dan nenas dicampur dengan rasio 3 bagian bahan organik, 1 bagian molase dan 10 bagian air bersih, kemudian difermentasi selama 3 bulan untuk menjadi larutan eco enzyme. Sampel hasil fermentasi tersebut diambil dan dianalisis untuk mengetahui parameter kimia berupa $\mathrm{pH}$, dan TDS dengan menggunakan prosedur pengujian yang ditetapkan. Hasil penelitian menunjukkan bahwa parameter $\mathrm{pH}$ untuk kedua buah cenderung asam yaitu pada 3,15 dan 3,29 selanjutnya untuk TDS memiliki kecenderungan yang relatif dekat yaitu, $1132 \mathrm{mg} / \mathrm{l}$ untuk nenas dan $1188 \mathrm{mg} / \mathrm{l}$ untuk pepaya. Diketahui juga bahwa larutan Eco enzym bemanfaat untuk berbagai kegiatan rumah tangga sekaligus dalam pengolahan air limbah.
\end{abstract}

Kata Kunci : eco enzyme, fermentasi, nenas, pepaya

\section{PENDAHULUAN}

Sampah adalah sisa kegiatan sehari-hari manusia atau proses alam yang berbentuk padat atau semi padat berupa zat organik atau an organik bersifat dapat terurai atau tidak dapat terurai yang dianggap sudah tidak berguna lagi dan dibuang ke lingkungan. Sampah Organik adalah barang/bahan yang dianggap sudah tidak terpakai dan dibuang oleh pemilik/pemakai sebelumnya, tetapi masih bisa dipakai kalau dikelola dengan prosedur yang benar (Chandra,2006). Sampah organik dapat juga dikatakan sebagai sampah yang bisa mengalami pelapukan (dekomposisi) dan terurai menjadi bahan yang lebih kecil dan tidak berbau (sering disebut dengan kompos) (Selamet, 2002). Kompos merupakan hasil pelapukan bahan-bahan organik seperti daun-daunan, jerami, alang-alang, sampah, rumput, dan bahan lain yang sejenis yang proses pelapukannya dipercepat oleh bantuan manusia. Sampah pasar khusus seperti pasar sayur mayur, pasar buah, atau pasar ikan, jenisnya relatif seragam, sebagian besar (56\%) berupa sampah organik sehingga lebih mudah ditangani (Nyimas Septi, 2016). Sampah yang berasal dari pemukiman umumnya sangat beragam, tetapi secara umum minimal $75 \%$ terdiri dari sampah organik dan sisanya anorganik.

Sampah yang sering dijumpai di lingkungan sekitar kita, seperti sisa-sisa makanan, kulit biji dari buah sayur, sampah buah-buahan, tulang ikan, serta dedaunan yang rotok dari pohon. Kelompok ini termasuk golongan sampah organik karena sifatnya yang dapat kita daur ulang,.

Salah satu langkah untuk memanfaatkan dan mengolah limbah organik adalah dengan mengkonversinya menjadi eco-enzyme. Eco enzyme merupakan larutan zat organik kompleks yang diproduksi dari proses fermentasi sisa sampah organik, gula, dan air. Cairan Eco-enzyme ini berwarna 
coklat gelap dan memiliki aroma asam/segar yang kuat.

Adapun manfaat dari eco enzyme sendiri adalah berdasarkan kegunaannya, dimana eco enzyme dapat dimanfaatkan sebagai pembersih serba guna, sebagai pupuk tanaman, sebagai pengusir berbagai hama tanaman dan sebagai pelestari lingkungan sekitar dimana eco enzyme dapat menetralisir berbagai polutan yang mencemari lingkungan sekitar. Eco enzyme yang ada bersumber dari penggunaan berbagai bahan baku organik seperti halnya buah-buahan dan sayur sayuran. Perbedaaan pada bahan baku tentunya akan memberikan efek yang berbeda pula pada hasil konversi proses yang dilakukan. Mengingat manfaat dan potensi penggunaannya di lingkungan, maka penulis memfokuskan penelitian adalah untuk mengetahui analisis komparasi atau perbandingan hasil konversi eco enzyme menggunakan bahan organik berupa buah nenas (Ananas comosus) dan pepaya (Carica papaya L.)

\section{TINJAUAN PUSTAKA}

\section{Pengertian Eco-enzyme}

Eco enzyme atau dalam Bahasa Indonesia disebut eko enzim merupakan larutan zat organik kompleks yang diproduksi dari proses fermentasi sisa organik, gula, dan air. Cairan Eco enzym ini berwarna coklat gelap dan memiliki aroma yang asam/segar yang kuat (M. Hemalatha, 2020). Bermula dari penemuan Dr. Rosukon Poompanvong, seorang peneliti dan pemerhati lingkungan dari Thailand. Inovasi ini memberikan distribusi yang cukup besar bagi lingkungan. Dr. Rosukon juga merupakan seorang pendiri Asosiasi PertanianOrganik Thailand (Organic Agriculture Association of Thailand) yang bekerjasama dengan petani di Thailand bahkan Eropa dan berhasil menghasilkan produk pertanian yang bermutu tetapi ramah lingkungan. Dari usaha dan inovasi yang dilakukan ini, ia dianugerahi penghargaan oleh FAO Regional Thailand pada tahun 2003.

\section{Kegunaan Eco-Enzyme}

Selama proses fermentasi, berlangsung reaksi :

$$
\mathrm{CO}_{2}+\mathrm{N}_{2} \mathrm{O}+\mathrm{O}_{2} \rightarrow \mathrm{O}_{3}+\mathrm{NO}_{3}+\mathrm{CO}_{3}
$$

Setelah proses fermentasi sempurna, barulah eco-enzyme (likuid berwarna coklat gelap) terbentuk. Hasil akhir ini juga menghasilkan residu tersuspensi di bagian bawah yang merupakan sisa sayur dan buah. Residu dapat dimanfaatkan sebagai pupuk organik. Sedangkan likuid eco-enzyme itu sendiri, dapat dimanfaatkan sebagai:

1. Pembersih lantai, sangat efektif untuk mebersihkan lantai rumah.

2. Disinfektan, dapat digunakan sebagai antibakteri di bak mandi.

3. Insektisida, digunakan untuk membasmi serangga (dengan mencampurkan ezim dengan air dan digunakan dalam bentuk spray).

4. Cairan pembersih di selokan, terutama selokan kecil sebagai saluran pembuangan air kotor.

Pembuatan enzim ini juga memberikan dampak yang luas bagi lingkungan secara global maupun ditinjau dari segi ekonomi. Ditinjau manfaat bagi lingkungan, selama proses fermentasi enzim berlangsung,dihasilkan gas $\mathrm{O} 3$ yang merupakan gas yang dikenal dengan sebutan ozon (Rubin, 2001). Sebagaimana diketahui jika satu kandungan dalam Eco Enzyme adalah Asam Asetat $\left(\mathrm{H}_{3} \mathrm{COOH}\right)$, yang dapat membunuh kuman, virus dan bakteri. Sedangkan kandungan Enzyme itu sendiri adalah Lipase, Tripsin, Amilase dan Mampu membunuh /mencegah bakteri Patogen. Selain itu juga dihasilkan $\mathrm{NO}_{3}$ (Nitrat) dan $\mathrm{CO}_{3}$ (Karbon trioksida) yang dibutuhkan oleh tanah sebagai nutrient. Dari segi ekonomi, pembuatan enzim dapat mengurangi konsumsi untuk membeli cairan pembersih lantai ataupun pembasmi serangga (Eviati \& Sulaeman. 2009).

Untuk membuat eco-enzyme, pertama yang harus dilakukan mempersiapkan bahan-bahan yang diperlukan seperti yang telah diuraikan di atas diantaranya 


\title{
Nenas (Ananas comosus)
}

Tanaman nenas termasuk tanaman kering yang banyak menyimpan air, Ananas comosus termasuk dalam tanaman CAM. Pada saat terjadi fotosintesis $\mathrm{CO}_{2}$ masuk ke dalam asam organik dan diikuti oleh transfer $\mathrm{CO}_{2}$ kedalam siklus Calvin yang hanya dipisahkan untuk sementara waktu. Fiksasi karbon kedalam asam organic terjadi pada saat malam hari yang sering disebut dengan metabolisme asam krasulase sedangkan untuk siklus Calvin terjadi pada saat siang hari. Tanaman seperti nenas ini membuka stomata pada saat malam hari dan menutup stomata pada saat siang hari serta pada sel mesofilnya mampu menyimpan asam organik yang dibuat dalam vakuola ketika malam hari sampai dengan pagi.

Nenas memiliki kandungan air 90\% dan kaya akan kalium, kalsium, fosfor, magnesium, zat besi, natrium, iodium, sulfur, dan khlor. Selain itu, kaya asam, biotin, vitamin A, vitamin B12, vitamin C, vitamin E, dekstrosa, sukrosa atau tebu, serta enzim bromelin, yaitu enzim protease yang dapat menghidrolisis protein, protease, atau peptide.(Bartolemeuw, 2003)

\section{Pepaya (Carica papaya L.)}

Carica papaya L. adalah semak berbentuk pohon dengan batang yang lurus dan bulat. Bagian atas bercabang atau tidak, sebelah dalam berupa spons dan berongga, sebelah luar banyak tanda bekas daun. Tinggi pohon 2,5-10 m, tangkai daun bulat berongga, panjang 2,5-10 m, daun bulat atau bulat telur, bertulang daun menjari, tepi bercangap, berbagi menjari, ujung runcing garis tengah $25-75 \mathrm{~cm}$, sebelah atas berwarna hijau tua, sebelah bawah hijau agak muda daun licin dan suram, pada tiap tiga lingkaran batang terdapat 8 daun. Bunga hampir selalu berkelamin satu atau berumah dua, tetapi kebanyakan dengan beberapa bunga berkelamin dua pada karangan bunga yang jantan. Buah buni bulat telur memanjang, biji banyak, dibungkus oleh selaput yang berisi cairan, didalamnya berduri. Berasal dari Amerika, ditanam sebagai pohon buah.

Kandungan gizi lengkap pepaya adalah terdiri dari : Energi, Serat, Protein, Karbohidrat, Kalsium, Fosfor, Kalium, Magnesium, Natrium, Zat besi, Karoten, Vitamin, Air. Selain kandungan gizinya, pepaya juga mengandung senyawa fitokimia, yaitu karotenoid. Pigmen karotenoid yang terdapat pada buah ini adalah likopen yang memberi warna merah (Redi Ramli, 2017).

\section{METODOLOGI PENELITIAN}

Penelitian dilaksanakan di Laboratorium Teknik Kimia Fakultas Teknik Universitas PGRI Palembang dan Laboratorium Terpadu Universitas PGRI Palembang.

\section{Bahan dan Alat}

Bahan yang digunakan dalam penelitian meliputi Bahan untuk pembuatan eco enzyme dan bahan untuk analisa, adapun bahan yang digunakan untuk pembuatan eco enzyme adalah buah nenas (Ananas comosus) tanpa mahkota dan buah papaya (Carica papaya L.) tanpa biji dan bahan pendukung seperti molase dan air bersih.

\begin{abstract}
Alat
Alat yang digunakan untuk pembuatan eco enzyme yaitu, ember 20 liter, pengaduk kayu, timbangan, pisau pemotong, sarung tangan, plastic, karet/tali rafia. Alat yang digunakan untuk analisa yaitu pipet Mohr/volum, bola karet, Erlenmeyer, gelas ukur $150 \mathrm{ml}, 250 \mathrm{ml}$, corong, kain penyaring, $\mathrm{pH}$ meter, indikator universal, TDS meter.
\end{abstract}

\section{Metode Penelitian}

Penelitian ini merupakan penelitian eksperimen dengan menggunakan bahan baku berupa buah nanas 
dan papaya yang dicampur dengan molase dan air bersih. Adapun rasio komposisi masing masing perlakuan tersebut yaitu : 1 bagian molase, 3 bagian buah dan 10 bagian air bersih.

\section{Prosedur}

Adapun cara pembuatannya :

a. Tuangkan air bersih ke dalam ember. Rasio air terhadap bahan bahan yang lain adalah 10 . Sedangkan rasio nenas dan pepaya adalah 3, dan rasio untuk molase adalah 1 . Sehingga perbandingannya menjadi Air : nenas/pepaya $:$ molase $=10: 3: 1$

b. Perlu diperhatikan bahawa akumulasi semua bahan yang akan dimasukkan ke dalam ember agar tidak memenuhi volume ember seutuhnya. Dibutuhkan ruang untuk gas hasil fermentasi.

c. Masukkan molase dan kemudian diaduk hingga terlarut dengan air - homogen. Molase berfungsi sebagai sumber gula bagi bakteri untuk melakukan fermentasi.

d. Masukkan nenas dan pepaya ke dalam ember masing-masing. Pepaya dan nenas yang dimasukkan hendaknya dipotong kecil, ditimbang sesuai ukuran-ratio yang telah ditentukan dan diremas sehingga berukuran kecil. Ini bertujuan agar proses fermentasi dapat berjalan dengan baik.

e. Semakin kecil ukuran nenas, maka bakteri dekomposer yang terkandung di dalamnya menjadi lebih teraktivasi untuk melakukan fermentasi karena luas bidang lebih kecil.

f. Setelah semua bahan tercampur dengan baik, tutup ember agar udara luar tidak masuk. Hal ini dapat menggangu proses fermentasi (agar lebih kedap dapat juga gunakan plastic yang diikat dengan karet atau tali rafia) lalu ditutup.

g. Enzim yang telah dibuat disimpan di tempat yang tidak terjangkau oleh cahaya matahari, sehingga sistem benar-benar tertutup.

h. Fermentasi sempurna memakan waktu hingga 3 bulan.

i. Pada dua minggu pertama setelah pembuatan, tutup ember dapat dibuka maksimal 2 kali selama beberapa detik saja membuang gas yang terbentuk (wadah yang bermulut kecil/botol).

\section{Parameter yang diamati}

Adapun parameter yang diamati dalam penelitian ini meliputi analisa kimia berupa $\mathrm{pH}$, dan TDS dari larutan eco enzyme yang dihasilkan.

\section{HASIL DAN PEMBAHASAN}

\section{Karakteristik Eco enzyme dari Buah Nenas dan Pepaya}

Pengujian untuk larutan eco enzyme dari buah nenas dan pepaya ini dilakukan dengan mengambil sampel larutan eco enzyme sebanyak $300 \mathrm{ml}$ dan selanjutnya diperiksa dan dianalisis. Karakteristik sampel Eco enzim yang disaring dianalisis setelah waktu tercapai. Parameter biokimia seperti $\mathrm{pH}$ dan TDS dianalisis sesuai prosedur dalam metode standar.

Hasil pengujian ini sejalan dengan penelitian terdahulu yang menunjukkan bahwa kecenderungan larutan eco enzyme yang dihasilkan dari bahan organik berupa buah menghasilkan parameter kimia bersifat asam dengan nilai $\mathrm{pH}$ rendah. Asam organik adalah kunci penting dalam penentuan keasaman. Artinya semakin tinggi kandungan asam organiknya, semakin rendah nilai $\mathrm{pH}$. Dengan demikian, eco enzym yang memiliki nilai $\mathrm{pH}$ rendah dalam penelitian ini sebagai akibat dari kandungan asam organik yang tinggi seperti asam asetat atau asam sitrat (Etienne, A.,2013) . Selain itu untuk larutan enzim yang ada yang dihasilkan dengan bahan organik berupa limbah buah atau limbah padat organik 
dan molase yang ditambahkan sebagai substrat dalam proses fermentasi mendorong faktor TDS yang tinggi pada eco enzyme (Selvakumar, P. 2015).

Sebagaimana hasil penelitian untuk buah nenas, diperoleh $\mathrm{pH}$ 3,15 dan pepaya 3,29. Untuk larutan enzim yang ada pada bahan baku nenas dan pepaya maka diindikasikan akumulasi bahan organic dan molase sebagai substrat dalam proses fermentasi mendorong faktor TDS yang tinggi pada eco enzyme.

Adapun perbandingan antara kedua bahan organik yaitu nenas dan papaya dalam larutan eco enzyme seperti pada table dan grafik berikut :

Tabel Parameter Uji larutan Eco enzyme dari Nenas dan Pepaya

\begin{tabular}{|c|c|c|}
\hline \multirow{2}{*}{ Bahan Organik } & \multicolumn{2}{c|}{ Parameter Pengujian } \\
\cline { 2 - 3 } & $\mathbf{p H}$ & TDS (mg/l) \\
\hline Nenas & 3.15 & 1188 \\
\hline Pepaya & 3.29 & 1132 \\
\hline
\end{tabular}

Sumber : Hasil Penelitian

Di sisi lain, salah satu masukan penting dalam pengolahan bahan organik yang dijadikan eco enzyme adalah adanya pengaruh waktu fermentasi, dimana nilai parameter kecuali $\mathrm{pH}$ akan berkurang seiiring waktu fermentasi karena degradasi bahan organik oleh mikroorganisme yang ada dalam larutan enzim (Nazim, F. \& Meera, 2013). Oleh karenanya, indikator $\mathrm{pH}$ yang diperoleh akan lebih tinggi karena parameter dianalisis segera setelah 3 bulan fermentasi berlangsung. Selain itu pengaruh yang juga penting adalah bahan organik yang digunakan untuk fermentasi.

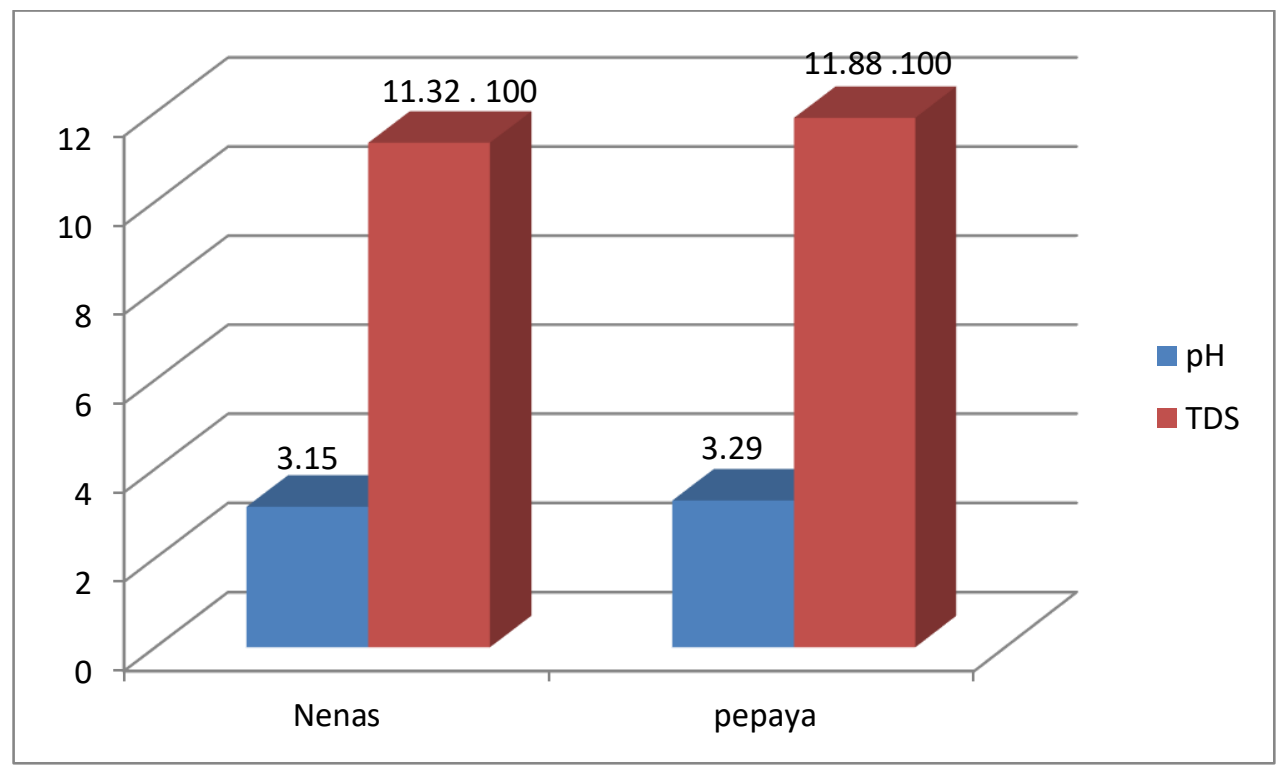

Grafik Parameter Uji larutan Eco enzyme dari Nenas dan Pepaya

Dalam penelitian lain juga menunjukkan bahwa terdapat pengaruh pada penggunaan molase dan gula merah dimana nilai parameter akan semakin rendah jika menggunakan gula molase dibandingkan dengan gula merah (Arun C., 2015). Hal ini dikarenakan gula molase adalah zat sisa dari produksi gula yang mengandung mikroorganisme yang aktif. 


\section{KESIMPULAN}

Hasil fermentasi kedua jenis buah nenas dan papaya menunjukkan Eco enzyme yang dihasilkan menjadi bersifat asam dengan $\mathrm{pH}$ yang rendah. Disamping itu lama waktu fermentasi dan penggunaan molase berpengaruh terhadap tingkat pH dan TDS yang dihasilkan. Oleh karenanya,, untuk lebih jauh dalam memanfaatkan teknologi eco enzyme dipandang perlu untuk mengembangkan penelitian dengan mengkombinasikan berbagai bahan organik dan dengan diikuti variasi waktu dan kondisi operasi.

\section{DAFTARPUSTAKA}

Arun, C. \& Sivashanmugam, P. (2015). Investigation of biocatalytic potential of garbage enzyme and its influence on stabilization of industrial waste activated sludge. Process Safety and Environmental Protection, 94, 471-478

Bartholomew DP, Paull RE and Rohrbach. (2003). The Pineapple: Botany, Productionand Uses. University of Hawaii at Manoa Honolulu USA. CABI Publishing

Chandra. 2006. Penghantar Kesehatan Lingkungan.EGC. Jakart

Etienne, A., Genard, M., Lobit, P., Mbeguie-Ambeguie, D. \& Bugaud, C.( 2013) What controls fleshy fruit acidity? A review of malate and citrate accumulation in fruit cells. Journal of Experimental Botany, 64(6), 1451-1469

Eviati \& Sulaeman. (2009). Analisa Kimia Tanah, Tanaman, Air Dan Pupuk. Bogor : Badan Penelitian Dan Pengembangan Pertanian Departemen Pertanian.

M. Hemalatha and P.Visantini, ((2020). Potential use of eco-enzyme for the treatment of metal based effluent. IOP Conf. Series: Materials Science and Engineering 716, 1-6

Nazim, F. \& Meera, V. (2013). Treatment of synthetic greywater using 5\% and 10\% garbage enzyme solution. International Journal of Industrial Engineering and Management Science, 3(4), 111-117.

Nyimas Septi Rika Putri, dkk. 2016. Studi Timbunan Sampah Perumahan Dan Non Perumahan Di Kota Palembang, Cantileve, 5 (2), 19-23

Redi Ramli1, Faizah Hamzah. (2017). Pemanfaatan Buah Pepaya (Carica Papaya L.,) Dan Tomat (Lycopersicum Esculentum Mill.,) Dalam Pembuatan Fruit Leather. Jom Faperta, 4 (1), 1-9

Rubin, M.B. (2001). The History of Ozone. The Schonbein Period, 1839- 1868. Bull. Hist. Chem. $26(1): 71-76$

Selamet, Juli Soemirat. (2002). Kesehatan Lingkungan. Penerbit Gajah Mada. University Press Yogyakarta

Selvakumar, P. \& Sivashanmugam, P.( 2015). Optimization of lipase production from organic solid waste by anaerobic digestion and its application in biodiesel production. Fuel Processing Technology, 165, 2017, 1-8. 